\title{
GENETIC DIVERSITY IN TYVA HORSES DERIVED FROM POLYMORPHISM OF BLOOD SYSTEMS AND MICROSATELLITE DNA
}

\section{R.B. CHYSYMA1, L.A. KHRABROVA², A.M. ZAITSEV ${ }^{2}$, E.Yu. MAKAROVA', Yu.N. FEDOROV' , B.M. LUDU 1}

\begin{abstract}
${ }^{1}$ Tyva Research Institute of Agriculture, Federal Agency of Scientific Organizations, 4, ul. Bukhtueva, Kyzyl, Tyva Republic, 667005 Russia, e-mail chysyma@mail.ru (corrresponding author);

${ }^{2}$ All-Russian Research Institute for Horse Breeding, Federal Agency of Scientific Organizations, pos. Divovo, Rybnovskii Region, Ryazan Province, 391105 Russia, e-mail Khrabrova@yandex.ru (corresponding author), amzaitceff@mail.ru;

${ }^{3}$ All-Russian Research and Technological Institute of Biological Industry, Federal Agency of Scientific Organizations, 17, pos. Biokombinata, Shchelkovskii Region, Moscow Province, 141142 Russia, e-mail fun181@mail.ru (corresponding author)
\end{abstract}

ORCID: Fedorov Yu.N. orcid.org/0000-0001-7268-3734

The authors declare no conflict of interests

Received October 13, 2016

\section{Abstract}

Tyva horse breed is one of the most promising local breeds of universal use. Tyva horses are well adapted to year-round pasture grazing, resistant to disease, and, therefore, suitable for lowcost meat production. Due to relatively isolated location of the population which has ancient origin uva horses are undoubtedly of interest both genetically and evolutionarily. For allele pool study we sampled blood $(n=32)$ and hair $(n=35)$ specimens from Tyva horses reared at two farms of Tyva Research Institute of Agriculture in 2009-2016. Genetic analysis was carried out according to the authority certified by ISAG (International Society of Animal Genetics). The study of polymorphic blood system and microsatellite DNA loci showed the Tyva horses to be fairly high genetically diverse on structural genes and microsatellite DNA. High polymorphism was found in $T f, A l, E s$ loci and especially in D system of blood groups. $D^{c g m}, D^{b c m}$ and $D^{d}$ alleles were comparatively highfrequent, while $D a^{d}, D^{d e}$ and $D^{d k}$ were relatively rare. As to microsatellite DNA polymorphism, there were 113 alleles in 17 loci ( 6.65 alleles per locus on average), indicating high genetic diversity in the Tyva horse breed. Amon the microsatellite DNA loci found, VHLP, AHT4P, HMS7J, ASB23 L, ASB2B, HMS3 N, ASB17Q, LEX3K, LEX3P, HMS1I, HMS1N and HMS1R were rare, of which HMS1R was unique as not found in horses of European origin (L.H.P. Van de Goor et al., 2010). There were from 4 to 9 alleles in the studied microsatellite loci, and the average number of effective allele per locus $\left(\mathrm{A}_{\mathrm{e}}\right)$ made 4.20 being rather high even for local breeds. Loci ASB17 (10 alleles), AHT4 (9 alleles), VHL20 (9 alleles), ASB2 (9 alleles) and ASB23 (8 alleles) were the most diverse. The genetic population analysis demonstrated good correspondence between the observed $\left(\mathrm{H}_{\mathrm{o}}=0.748\right)$ and the expected $\left(\mathrm{H}_{\mathrm{e}}=0.742\right)$ heterozygosis level and the absence of inbreeding $\left(\mathrm{F}_{\mathrm{IS}}=-0.008\right)$ in the Tyva horses. The highest similarity was found out between Tyva horse and Khakass horse (0.823), and also between Tyva horse and Mongolian horse (0.822) which areas border on the South and South-East. The data of whole genome association analysis (J.R. Mickelsn et al., 2012) are also in line with genetic distance that we calculated based on 17 microsatellite loci polymorphism. The visualized dendrogramm indicated common origin of the Tyva and Mongolian horses, which make a common branch in the evolutionary tree of horse breeds. Our findings indicate a high level of genetic plasticity of Tyva horses promising for breeding. In general, we can conclude that the studied population of Tyva horses is characterized by the original allele pool, including a number of rare alleles that must be preserved in the breed at rearing and genetic improvement.

Keywords: genetic diversity, microsatellite DNA, polymorphic blood systems, population analysis, Tyva horse

Domestic stud and local breeds of horses, well adapted to local climatic conditions and resistant to diseases, often have a unique allelic pool which is a significant breeding reserve [1].

Genetic markers allow monitoring of genealogical structure of populations, matching and selection of animals for breeding programs that take into 
account the genotype [2-5]. Using the microsatellite analysis, the gene pool, the composition of populations, phylogenetic connections in a number of unique native breeds of horses, Khakass and other aboriginal Siberian breeds [6-8], Budennovskaya [9], Bashkir [10] and Karachai [11], were studied. Microsatellites are used for molecular genetic comparison of lines and families [12, 13], estimation of genetic diversity [14, 15] and breed stability [16], for marking genotypes, control of origin [17-19], and in gene flow studies [20]. Microsatellites can be combined with polymorphism markers of structural or mitochondrial genes $[17,21,22]$. Blood group systems due to the codominant type of inheritance of antigenic factors, broad polymorphism and relatively easy assessment $[23,24]$ also remain important markers in population studies [25-28].

The Tyva horse (Equus ferus caballis), which is related in origin to the Mongolian one but is larger in size, is valued for its adaptability to year-round pasture maintenance in herds out of premises. It is more resistant to abiotic and biotic stressors, including pathogens, and is less susceptible to disease [29]. The horse farms of the republic contain 68.1 thousand heads [30]. They are mainly used for meat, and the body weight of mares by the end of the pasture period averages $316 \pm 7.2 \mathrm{~kg}$. In the livestock structure the mares are $35.2-42.5 \%$, the yield of foals is 58 heads per 100 mares [31]. The production of horse meat is almost 3 times cheaper than beef. This, along with the availability of favorable conditions and demand, determines the desirability of breeding local horses and raising their meat productivity which is relatively small. At the same time, it is important to preserve the valuable adaptive qualities of the breed. Therefore, in selection and breeding, it is necessary to take into account not only the phenotype, but also the genotypic characteristics of animals.

It should be noted that only one work in which the systems of polymorphic blood proteins were studied [24] was devoted to the immunogenetic traits of Tyva horses, and DNA microsatellite loci test was just recently started. Here, this is the first complex study of the Tyva horse population for combination of immunogenetic markers, such as polymorphic proteins (transferrin, albumin, esterase) and blood group systems, together with DNA microsatellites, which allows us to significantly expand the range of markers for genetic selection programs.

The purpose of this work was to analyze the genetic structure of the Tyva horse population based on the prevalence of the loci of polymorphic blood systems and polymorphism of DNA microsatellites.

Techniques. The research was carried out in 2009-2016 at the basic farms of the Tyva Agricultural Research Institute (GUP Bai-Tal and KFKh BeecheShivilig; Bai-Taiginskii and Kyzylski regions, Tyva Republic) on Tyva breed horses (Equus feru scaballis). The biomaterial was blood samples $(n=32)$ and hair samples with a hair follicle $(n=35)$. When selecting horses for the study, the exterior, body color and weight, and the presence of aboriginal features were evaluated. The whole year the animals were kept on pasturage.

Genotypes on the loci of blood proteins and enzymes were determined by horizontal electrophoresis in starch gel according to the recommendations [32], antigens of blood group systems were studied by hem agglutination with monospecific sera produced by the All-Russian Research Institute of Horse Breeding (certified by the International Society of Animal Genetics, ISAG) which were identified with international standards.

DNA was extracted from hair follicles using Diatom ${ }^{\mathrm{TM}}$ DNA Prep and ExtraGene $^{\mathrm{TM}}$ DNA Prep kits (OOO Isogen, Moscow). Amplification was performed using StockMarks for Horses Genotyping Kit Equine (Thermo Fisher Scientific, Inc., USA) in a 2720 Termal Cycler (Applied Biosystems, Inc., USA) 
with a set of primers for 17 microsatellite loci recommended by ISAG. Electrophoresis of the amplification products was carried out in an automatic 4capillary 3130 DNA Analyzer (Applied Biosystems, Inc., USA). Decoding and documentation of the results was carried out using the GeneMapper ${ }^{\mathrm{TM}}$ v.4.0 software (Applied Biosystems, Inc., USA).

To characterize the allelic pool, the average number of alleles $(\mathrm{Na})$ and the number of effective alleles $(\mathrm{Ne})$ per locus, observed $\left(\mathrm{H}_{\mathrm{o}}\right)$ and expected $\left(\mathrm{H}_{\mathrm{e}}\right)$ heterozygosity, and polymorphism indexes $\left(\mathrm{A}_{\mathrm{e}}\right)$ were calculated. Gene balance in the population, genetic similarity and genetic distance were assessed by conventional methods [33, 34].

Cluster analysis was performed on the basis of calculation of genetic distances between breeds based on the frequency of microsatellite loci alleles by M. Nei [34]. In comparing the genetic structure of the Tyva horse with other breeds, previously published data were used [3, 8].

Data statistical processing was carried out in MS Excel 2003 and Statistica 6 softwares (StatSoft Inc., USA). The table shows the mean $(X)$ and standard errors of the mean $( \pm x)$. Differences among the values were considered statistically significant at $\mathrm{P}>0.95$.

Results. Analysis of blood group systems $(n=17)$ and polymorphic blood protein systems $(n=15)$ revealed a distinctive pedigree uniqueness of the genetic structure of the Tyva horses, despite a small number of studied animals. In the transferrin system, 5 alleles were detected, $T f^{D}, T f^{F}, T f^{H}, T f^{R}$ и $T f^{O}$. In the population allele pool, $T f^{F}$ allele prevailed with the frequency of 0.324 ; the frequency of $T f^{H}$ and $T f^{R}$ alleles was almost the same (0.235). The $T f^{O}$ allele (0.029) was comparatively rare. In the albumin locus, two alleles were found, $A L B^{A}$ and $A L B^{B}$, of which $A L B^{B}$ prevailed (0.559). In the esterase locus, there were 3 alleles, $E S^{F}, E S^{G}$ и $E S^{I}$. In the studied horses, the $E s^{I}$ allele was the most common (0.559) while $E S^{F}(0.206)$ and $E S^{G}(0.235)$ were relatively less frequent.

We determined the frequency of antigens of the three genetic blood systems (A, K, and D). For EAA system, the Tyva horses were carriers of the blood marker $A^{a}$ (Table 1). For EAK system, antigens were found indicating the presence of $K^{a}$ and $K^{-}$alleles with relatively more frequent $K^{a}$ allele $(0.2941 \pm 0.1110)$.

1. Frequency of blood group system loci in Tyva horses $(X \pm x, n=17$, Bai-Taiginsky and Kyzylsky regions, Republic of Tyva, 2009-2016)

\begin{tabular}{c|l|l|c|c|c}
\hline \multicolumn{2}{c|}{ EAA system } & \multicolumn{2}{c|}{ TAD system } & \multicolumn{2}{c}{ EAK system } \\
\hline genotype & frequency & genotype & frequency & genotype & frequency \\
\hline$A^{a}$ & $1,00 \pm 0,00$ & $D^{a d / d}$ & $0.0588 \pm 0.0570$ & $K^{a}$ & $0.2941 \pm 0.1110$ \\
& $D^{b c m / d g h m}$ & $0.0588 \pm 0.0570$ & $K^{-}$ & $0.7059 \pm 0.1110$ \\
& $D^{b c m / c g m}$ & $0.1176 \pm 0.0780$ & & \\
& $D^{b c m / d}$ & $0.1176 \pm 0.0780$ & \\
& $D^{c g m / d}$ & $0.0588 \pm 0.0570$ & \\
& $D^{c g m / d e}$ & $0.1765 \pm 0.0920$ & \\
& $D^{\operatorname{cgm} / d k}$ & $0.0588 \pm 0.0570$ & \\
& $D^{\operatorname{cgm} / \mathrm{cgm}}$ & $0.0588 \pm 0.0570$ & \\
& $D^{\mathrm{cgm} / \mathrm{dghm}}$ & $0.2941 \pm 0.1110$ & \\
\end{tabular}

A great variety was found in the frequency of EAD antigenic factors. In horses, this blood group system is the most complex, includes 17 antigens that form more than 30 phenogroups, and is considered as the most informative for understanding breed genesis. The data obtained by us (see Table 1) indicated the dominance of the genotype $D^{\mathrm{cgm} / \mathrm{dghm}}$ in the local breed, with the frequency of $29.41 \%$. Alleles $D^{c g m}, D^{b c m}$ and $D^{d}$ showed a relatively high frequency, and $D^{a d}, D^{d e}$ and $D^{d k}$ were relatively rare.

When studying the polymorphism of microsatellite DNA in Tyva horses, 113 alleles were found in 17 loci, or on average 6.65 alleles per locus, 
which indicates a high genetic diversity of the breed (Table 2). In a number of

2. The frequency of heterozygosity $\left(\mathrm{H}_{\mathrm{o}}\right)$ for 17 microsatellite loci in Tyva horses $(X \pm x, n=35$, Bai-Taiginsky and Kyzylsky regions, Republic of Tyva, 20092016)

\begin{tabular}{|c|c|c|c|}
\hline \multirow{2}{*}{ Locus } & \multicolumn{2}{|r|}{ Alleles } & \multirow{2}{*}{$\mathrm{H}_{\mathrm{o}}$} \\
\hline & number & set & \\
\hline VHL20 & 9 & $\mathrm{I}, \mathrm{J}, \mathrm{L}, \mathrm{M}, \mathrm{N}, \mathrm{O}, \mathrm{P}^{*}, \mathrm{Q}, \mathrm{R}$ & 0.771 \\
\hline HTG4 & 6 & $\mathrm{~K}, \mathrm{~L}, \mathrm{M}, \mathrm{N}, \mathrm{O}, \mathrm{P}^{*}$ & 0.600 \\
\hline AHT4 & 9 & $\mathrm{H}, \mathrm{I}, \mathrm{J}, \mathrm{K}, \mathrm{L}, \mathrm{M}, \mathrm{N}, \mathrm{O}, \mathrm{P}^{*}$ & 0.857 \\
\hline HMS7 & 5 & $\mathrm{~J}^{*}, \mathrm{~L}, \mathrm{M}, \mathrm{N}, \mathrm{O}$ & 0.771 \\
\hline HTG6 & 5 & $\mathrm{G}, \mathrm{I}^{*}, \mathrm{~J}, \mathrm{M}^{*}, \mathrm{O}$ & 0.714 \\
\hline AHT5 & 6 & $\mathrm{~J}, \mathrm{~K}, \mathrm{~L}, \mathrm{M}, \mathrm{N}, \mathrm{O}$ & 0.743 \\
\hline HMS6 & 5 & $\mathrm{~K}, \mathrm{~L}, \mathrm{M}, \mathrm{O}, \mathrm{P}$ & 0.857 \\
\hline ASB23 & 8 & $\mathrm{G}^{*}, \mathrm{H}^{*}, \mathrm{I}, \mathrm{J}, \mathrm{K}, \mathrm{L}, \mathrm{S}, \mathrm{T}, \mathrm{U}$ & 0.857 \\
\hline ASB2 & 9 & $\mathrm{~B}^{*}, \mathrm{C}^{*}, \mathrm{I}^{*}, \mathrm{~K}, \mathrm{M}, \mathrm{N}, \mathrm{O}, \mathrm{P}, \mathrm{Q}$ & 0.800 \\
\hline HTG10 & 7 & $\mathrm{I}^{*}, \mathrm{~K}, \mathrm{M}, \mathrm{O}, \mathrm{Q}, \mathrm{R}, \mathrm{S}^{*}$ & 0.714 \\
\hline HTG7 & 4 & $\mathrm{~K}, \mathrm{M}, \mathrm{N}, \mathrm{O}$ & 0.829 \\
\hline HMS3 & 6 & $\mathrm{I}, \mathrm{M}, \mathrm{N}^{*}, \mathrm{O}, \mathrm{P}, \mathrm{Q}, \mathrm{R}$ & 0.886 \\
\hline HMS2 & 5 & $\mathrm{H}, \mathrm{I}, \mathrm{J}, \mathrm{K}, \mathrm{L}$ & 0.794 \\
\hline ASB17 & 10 & $\mathrm{G}, \mathrm{I}, \mathrm{J}, \mathrm{K}, \mathrm{L}, \mathrm{N}, \mathrm{P}, \mathrm{Q}^{*}, \mathrm{R}$ & 0.943 \\
\hline LEX3 & 7 & $\mathrm{~F}, \mathrm{H}, \mathrm{I}, \mathrm{L}, \mathrm{M}, \mathrm{N}, \mathrm{P}$ & 0.886 \\
\hline HMS1 & 6 & $\mathrm{I}^{*}, \mathrm{~J}, \mathrm{~K}, \mathrm{M}, \mathrm{N}^{*}, \mathrm{R}^{*}$ & 0.514 \\
\hline CA425 & 6 & I, K, L, M, N, O & 0.800 \\
\hline
\end{tabular}

loci, rare alleles VHLP, AHT4P, HMS7J, ASB23L, ASB2B, HMS3N, ASB17Q, LEX3K, LEX3P, HMS1I, HMS1N and HMS1R were revealed. It should be specially noted that the Tyva horses have a very rare HMS1R (0.014) allele that is not found in the populations of horses of European origin [18].

Test showed that Tyva horses are characterized by significant polymorphism in a number of microsatellite loci. This indicates a very high genetic diversity in the population. In the studied microsatellite loci, from 4 to 9 alleles were identified, the average number of effective alleles per locus $\left(\mathrm{A}_{\mathrm{e}}\right)$ was 4.20 , which is considered to be a sufficiently high index even for local horse breeds. The loci ASB17 (10 alleles), ANT4, VHL20 and ASB2 (9 alleles) and ASB23 (8 alleles) were the most diverse. Cluster analysis confirmed the uniqueness of the genetic structure of the Tyva breed (Fig.).

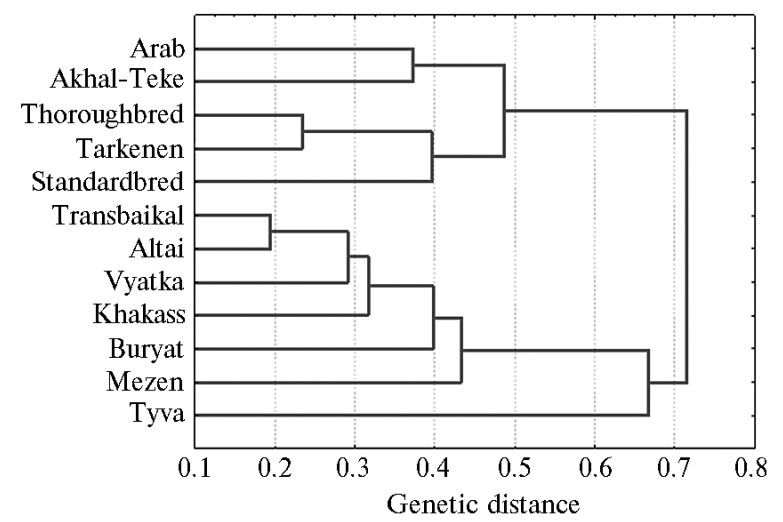

Dendrogram of genetic distances according to $M$. Nei between horse breeds based on 17 DNA microsatellite loci (data by V.V. Kalashnikov et al.) $[3]$.

When surveying horses in KFKh Beeche-Shivilig $(n=11), 12$ additional alleles were found in 9 out of the 16 studied microsatellite loci, which occurred at a frequency of $<5 \%$ that indicates high genetic plasticity

of the breed. The average value of $\mathrm{H}_{\mathrm{o}}$ for microsatellite loci in Tyva horses from this farm was 0.721 with fluctuations from 0.480 to 0.960 .

Genetic population analysis demonstrated good compliance of the observed $\left(\mathrm{H}_{\mathrm{o}}=0.748\right)$ and expected $\left(\mathrm{H}_{\mathrm{e}}=0.742\right)$ heterozygosity for microsatellite loci, and the absence of inbreeding in the Tyva horse $\left(\mathrm{F}_{\mathrm{IS}}=-0.008\right)$. When comparing the breeds, Tyva and Khakass (0.823) and Tyva and Mongolian (0.822) horses, which areas border on the south and southeast, showed the greatest genetic similarity. The common origin of the Tyva and Mongolian horses which form a common branch in the tree of caballine breed evolution is also confirmed by a full-genome analysis [35].

Thus, our study of the loci encoding blood systems and microsatellite DNA showed that the Tyva horse exhibits genetic variability on the alleles of both structural genes and microsatellites. Of the structural genes, the transferrin, albumin, esterase, and especially the D blood group loci, with both frequent and 
relatively rare alleles, were the most polymorphic. Polymorphism of microsatellite DNA averaged 6.65 alleles per locus which indicates a high genetic diversity. In a number of loci, rare alleles and the HMS1R allele which is not found in European horses are identified. Loci ASB17, ANT4, VHL20, ASB2 and ASB23 were the most diverse. Tyva horse is genetically the most similar to the Khakass (0.823) and Mongolian (0.822) breeds which areas border on that of Tyva horse. It is important to keep the original allele pool of the Ttva horse, which includes a number of rare alleles, for further breeding and selection. Improvement of the Tyva horse which is characterized by genetic plasticity seems to be very promising.

\section{REFEREN C ES}

1. Khrabrova L.A., Z a itsev A.M., Yur'eva I.B., Vdovina N.V. Metodicheskie rekomendatsii po vedeniyu geneticheskogo monitoringa mestnykh porod loshadei [Genetic monitoring of local horse breeds - recommendations]. Divovo, 2005 (in Russ.).

2. Ernst L.K., Z inov'eva N.A. Biologicheskie problemy zhivotnovodstva v XXI veke [Biological aspects of animal husbandry in the XXI century]. Moscow, 2008 (in Russ.).

3. Kalashnikov V.V., Khrabrova L.A., Z a itsev A.M., Z a i ts eva M.A., Ka li nk ova A.A. Polymorphism of microsatellite DNA in horses of stud and local breeds. Sel'skokhozyaistvennaya biologiya [Agricultural Biology], 2011, 2: 41-45 (in Russ.).

4. Zinovieva N.A., Kostyunina O.V., Gladyr' E.A., B annikova A.D., Kharzi nova V.R., Larionova P.V., Shavyrina K.M., Ernst L.K. Zootekhniya, 2010, 1: 8-10 (in Russ.).

5. Z a i ts e v A.M., K a la s hnik ov V.V., Kove s h nik o v V.S. Materialy konferentsii «Aborigennye porody loshadei: ikh rol' i mesto v konevodstve Rossiiskoi Federatsii» [Proc. Conf. «Role of native horses in the Russian horse breeding»]. Izhevsk, 2016: 51-55 (in Russ.).

6. De rgu nova M.M., Kolo me e t s Yu.Yu., Khrabrova L.A. Konevodstvo $i$ konnyi sport, 2012, 6: 8-9 (in Russ.).

7. Kuznetsova M.M. Geneticheskaya struktura $i$ filogeneticheskie svyazi aborigennykh porod loshadei Zapadnoi Sibiri. Kandidatskaya dissertatsiya [Genetic structure and phylogenetic connections among native West Siberian horses. PhD Thesis]. Dubrovitsy, 2011 (in Russ.).

8. K h rabrova L.A. Materialy Mezhdunarodnoi konferentsii «Aktual'nye problemy zhivotnovodstva» [Proc. Int. Conf. «Actual problems of animal husbandry»]. Moscow, 2009: 92-95 (in Russ.).

9. Khrabrova L.A., Kurnyavko N.Yu., Sotnikova S.A. Konevodstvo $i$ konnyi sport, 2012, 3: 6-8 (in Russ.).

10. Shi ri ev V.M., U razbakhti n R.F., Ga i nulli na K.P. Vestnik rossiiskoi sel'skokhozyaistvennoi nauki, 2014, 5: 13-15 (in Russ.).

11. Erke nov T.A., G 1 a z k o V.I. Integral, 2013, 3: 36-38 (in Russ.).

12. Khrabrova L.A. Materialy konferentsii «Aborigennye porody loshadei: ikh rol' $i$ mesto $v$ konevodstve Rossiiskoi Federatsii» [Proc. Conf. «Role of native horses in the Russian horse breeding»]. Izhevsk, 2016: 171-177 (in Russ.).

13. K h rabrova L. Characterization of genetic horse breeding resources in Russia. Lambert Academic Publishing, 2015.

14. Ling Y.H., Ma Y.H., Guan W.J., Cheng Y.J., Wang Y.P., Han J.L., Mang L., $\mathrm{Zh}$ a o Q.J., He X.H., P u Y.B., F u B.L. Evaluation of the genetic diversity and population structure of Chinese indigenous horse breeds using 27 microsatellite loci. Anim. Genet., 2011, 42(1): 56-65 (doi: 10.1111/j.1365-2052.2010.02067.x).

15. $\mathrm{Cunn}$ ing h a m E.P. Molecular methods and equine genetic diversity. In: Conservation genetics of endangered horse breeds. EAAP publication No 116. Bled, Slovenia, 2005: 15-24.

16. Campana M.G., Stock F., Barrett E., Benecke N., Barker G.W.W., S e t a h K., B owe r M.A. Genetic stability in the Icelandic horse breed. Animal Genetics, 2011, 43: 447-449.

17. Koban E., Denizci M., Aslan O., Aktoprakligil D., Aksu S., Bower M., Balcioglu B.K., Ozdemir Bahadir A., Bilgin R., Erdag B., Bagis H., Arat S. High microsatellite and mitochondrial diversity in Anatolian native horse breeds shows Anatilia as a genetic conduit between Europe and Asia. Anim. Genet., 2011, 43(3): 401-409 (doi: 10.1111/j.1365-2052.2011.02285.x).

18. Van de Goor L.H.P., Panneman H., Haeringen W.A. A proposal for standardization in forensic equine DNA typing: allele nomenclature for 17 equine-specific STR loci. Anim. Genet., 2010, 41(2): 122-127 (doi: 10.1111/j.1365-2052.2009.01975.x).

19. Mel'nik O.V., Dzitsyuk V.V., Spiridonov V.G. Izvestiya Orenburgskogo GAU, 2013, 6(44): 128-131 (in Russ.).

20. Achmann R., Curik I., Dovc P., Kavar T., Bodo I., Habe F., Marti E., Solkne r J., B re m G. Microsatellite diversity, population subdivision and gene flow in the Lipizzan 
horse. Anim. Genet., 2004, 35: 285-292.

21. Luis C., Juras R., Oom M.M., Cothran E.G. Genetic diversity and relationships of Portuguese and other horse breeds based on protein and microsatellite loci variation. Anim. Genet., 2007, 38(1): 20-27.

22. Keyser-Tracqui C., Blandin-Frappin P., Francford H.-P., Ricaut F-X., Lepetz S., Crubezy E., S a mashev Z., Ludes B. Mitochondrial DNA analysis of horses recovered from a frozen tomb (Berel site, Kazakhstan, $3^{\text {rd }}$ Century BC). Anim. Genet., 2005, 36(3): 203-215.

23. Dubrovskaya R.M., Starodumov I.M., Bannikova L.V. Genetika, 1992, 28(4): 152165 (in Russ.).

24. Mongush A.N., Ol'khovskaya L.V., Krivoruchko S.V. Sbornik nauchnykh trudov Vserossiiskogo NII ovtsevodstva i kozovodstva (Stavropol'), 2009, 1(1): 99-100 (in Russ.).

25. De rgu nova M.M., Kolome ets Yu.Yu., Khrabrova L.A. V sbornike: Problemy razvitiya APK Sayano-Altaya [In: Actual aspects of the agroindustrial development of Altai-Sayan]. Abakan, 2011 (in Russ.)

26. Jiskrová I., Glas nák V., M is a D. The use of blood protein polymorphism for determining the genetic distance between the Moravian warm-blooded horse and the Czech warmblooded and Trakehner horses. Czech J. Anim. Sci., 2002, 47(3): 98-105.

27. Vinocur M.E., Brass K.E., Rubin M.I., Silva C.A.M. Genetic variability in the Brazilian criollo horse breed. Ciência Rural, 2003, 33(1): 137-142.

28. Nunes R.L., Oliveira D.A.A., C oelho E.G.A. Polymorphism of serum proteins in Campolina horses. Anim. Reprod., 2005, 2(1): 60-62.

29. Chysyma R.B., Fedorov Yu.N., Makarova E.Yu., Kuular G.D. Humoral and cell factors of natural resistance in the animals of local breeds in specific environmental conditions of the Tyva Republic. Sel'skokhozyaistvennaya biologiya [Agricultural Biology], 2015, 6: 847-852 (doi: 10.15389/agrobiology.2015.6.847rus).

30. Pogolov'e skota v Respublike Tyva na 01.01.2016 g. (stat. sbornik) [Livestock in Tyva Republic at January 1, 2016: statistical compendium]. Kyzyl, 2016 (in Russ.).

31. Irgit R.Sh., Sambuu-Khoo Ch.S., Makarova E.Yu., Kan-Ool B.K. Informatsionnyi byulleten' o sostoyanii razvitiya konevodstva $v$ Respublike Tyva [Horse breeding in Tyva Republic (information bulletin)]. Kyzyl, 2003 (in Russ.).

32. Dubrovsk y a P.M. Metodicheskie rekomendatsii po ispol'zovaniyu polimorfnykh sistem belkov $i$ grupp krovi pri kontrole dostovernosti proiskhozhdeniya loshadei [Application of polymorphic blood group systems and proteins in the horse origin control (recommendations)]. Divovo, 1986 (in Russ.).

33. Kulikov L.V., Nikishev A.A. Matematicheskoe obespechenie eksperimenta v zhivotnovodstve [Mathematical methods in animal husbandry experiments]. Moscow, 2006 (in Russ.).

34. Ve ir B. Analiz geneticheskikh dannykh [Genetic data analysis]. Moscow, 1995 (in Russ.).

35. Mickelson J.R., Petersen J.L., Mccue M.E. Genetic variation in horse breeds derived from whole genome SNP data. In: Book of Abstracts of the 63 $3^{\text {rd }}$ Annual Meeting of the European Federation of Animal Science (Bratislava, Slovakia). Wageningen Academic Publishers, Wageningen, 2012, No 18: 326. 